\title{
Influence of Crude Protein Intake on the Duration of Delivery and Litter Size in Sows
}

\author{
D. TYDLITÁT ${ }^{1}$, A. VINKLER ${ }^{2}$, L. CZANDERLOVÁ $^{1}$ \\ ${ }^{1}$ Sevaron Consulting, ltd., Brno, Czech Republic \\ ${ }^{2}$ Clinic of Swine Diseases, Faculty of Veterinary Medicine, University of Veterinary and Pharmaceutical \\ Sciences Brno, Czech Republic
}

Received November 3, 2006

Accepted February 14, 2008

\begin{abstract}
Tydlitát D., A. Vinkler, L. Czanderlová: Influence of Crude Protein Intake on the Duration of Delivery and Litter Size in Sows. Acta Vet. Brno 2008, 77: 25-30.

The aim of the study was to evaluate the influence of different intakes of crude protein during the period from 94 to 100 days of pregnancy to the parturition, lengths of pregnancy and delivery, number and birth weights of piglets and concentrations of progesterone, $17-\beta$ estradiol and cortisol on days 100, 110 and 114 of pregnancy in sows. Daily feed intake of the sow represented $2.5 \mathrm{~kg}$ of complete mixtures containing 13\% (group A, $n=23$ ), 15\% (group B, $n=52$ ), 18\% (group C, $\mathrm{n}=10$ ) and $21 \%$ (group $\mathrm{D}, \mathrm{n}=10$ ) of crude protein. Lengths of pregnancy in experimental groups were not significantly different. The mean durations of delivery synchronously increased with the intake of crude protein; significant difference was found between groups A (4.5 h) and D (8.6 h) $(p<0.05)$. Total numbers of piglets in experimental groups were not significantly different. Numbers of live piglets decreased and numbers of stillborn piglets increased from groups A to D. Significant difference was found between numbers of stillborn piglets in group A compared to groups $\mathrm{C}, \mathrm{D}$; and group $\mathrm{B}$ compared to groups $\mathrm{D}, \mathrm{C}(p<0.05)$. The average birth weights of piglets did not differ between experimental groups. No statistical differences in hormone concentrations were found between experimental groups. High intake of crude protein in sows before parturition prolonged delivery and increased the number of stillborn piglets.
\end{abstract}

Nutrition, parturition, piglets, progesterone, 17- $\beta$ oestradiol, cortisol

Nutrition represents an important factor influencing reproduction in pigs. The amount of energy provided to the sow during pregnancy should be sufficient to cover the basic needs of the organism and demands of foetuses as well as mammary gland development. Thus, the metabolic requirements vary depending on the stage of pregnancy. Nutritional needs increase especially in the last third of pregnancy when the foetuses grow rapidly. The difference in the energy needs in the early and late gestation is about 3 to $12 \%$ of the maternal energy intake. The requirement of protein ranges from 7 to $41 \%$ of the maternal dietary protein intake (Noblet et al. 1985). For this reason it is desirable to increase the nutrient intake by $10 \%$ in sows and about $15 \%$ in gilts in the last month of pregnancy (Pond 1973). Greenhalgh et al. (1977) recommend the daily intake of $1.9 \mathrm{~kg}$ of mixture containing $9 \%$ of protein until day 80 of pregnancy and then to increase the content of protein to $12 \%$. Because of the physiological course of delivery, however, it is important to prevent overfeeding in the last 5 - 10 days of pregnancy and it is common practice to rapidly decrease the nutrient intake $24-36 \mathrm{~h}$ before farrowing. On the other hand, sows are able to mobilize their body deposits in order to ensure survival of foetuses in case of insufficient intake of proteins during pregnancy (Pond et al. 1969; Pond 1973). However, inadequate rate of catabolism by the end of pregnancy and during lactation causes oestrous delay after weaning (Britt 1986). The objective of our study was to evaluate the course of delivery, number and birth weights of piglets and concentrations of progesterone, 17- $\beta$ oestradiol and cortisol just before delivery in sows that were fed diets containing different amounts of crude protein as well as metabolisable energy during the last 14 days of pregnancy.

Address for correspondence:

MVDr. David Tydlitát

Sevaron, ltd.

Palackeho 163a, 62100 Brno

Czech Republic

Phone: +420 541426373

Email: david@ sevaron.cz

http://www.vfu.cz/acta-vet/actavet.htm 


\section{Materials and Methods}

Experimental animals

The trial was conducted at a pig farm keeping 1,000 sows (crossbreds of Large White and Czech Landrace). Monitoring was carried out in pregnant sows $\left(1.5\right.$ to 3 years old $-2^{\text {nd }}$ to $5^{\text {th }}$ parity in their $2^{\text {nd }}$ to $5^{\text {th }}$ pregnancy - the proportion of parities was the same within all groups) that were transferred to the farrowing house (within 94 and 100 day of pregnancy) by the end of March and at the beginning of April 2005. These sows were fed with $2.5 \mathrm{~kg}$ mixtures with different contents of crude protein and metabolisable energy from transfer to the farrowing house to the delivery. The sows were not fed on the day of delivery. Group A sows $(n=27)$ were fed a full feed mixture for farrowing sows from their transfer into the farrowing house. The feed mixture was compounded from $70 \%$ of barley corn, $5 \%$ of wheat corn, $17 \%$ of wheat bran, $5 \%$ of soy-extracted groats and $3 \%$ of feed mineral supplement. It contained $134.24 \mathrm{~g}$ of nitrogenous substances $/ \mathrm{kg}$ and $11.87 \mathrm{MJ} / \mathrm{kg}$ of pig metabolisable energy. The daily intake in the period from the transfer into the farrowing house until delivery was $335.6 \mathrm{~g}$ of crude protein and 29.68 MJ of metabolisable energy.

Group B sows $(n=53)$ were fed a full feed mixture for lactating sows from the transfer into the farrowing house. The feed mixture was compounded of $46 \%$ of barley corn, $35 \%$ of wheat corn, $3 \%$ of wheat bran, $9.5 \%$ of soy-extracted groats, $3.5 \%$ of rape-extracted groats and $3 \%$ of a feed mineral supplement. It contained $158.21 \mathrm{~g}$ of nitrogenous substances $/ \mathrm{kg}$ and $12.54 \mathrm{MJ} / \mathrm{kg}$ of pig metabolisable energy. The daily intake of crude protein in the period from the transfer into the farrowing house until delivery was $395.5 \mathrm{~g}$ and the daily intake of metabolisable energy was $31.35 \mathrm{MJ}$.

Group C sows $(\mathrm{n}=10)$ were fed a feed mixture compounded of $12 \%$ of barley corn, $33 \%$ of wheat corn, $17 \%$ of maize, $11 \%$ of soy-extracted groats, $8 \%$ of soy oil, $11 \%$ of thermally treated soy, $5 \%$ of rape pressings and $3 \%$ of a feed mineral supplement. It contained $179.31 \mathrm{~g}$ of nitrogenous substances $/ \mathrm{kg}$ and $15.36 \mathrm{MJ} / \mathrm{kg}$ of $\mathrm{pig}$ metabolisable energy from the transfer into the farrowing house. The daily intake of crude protein in the period from the transfer into the farrowing house until delivery was $448.3 \mathrm{~g}$ and the daily intake of metabolisable energy was $38.40 \mathrm{MJ}$.

Group D sows $(n=10)$ were fed a feed mixture compounded of $29 \%$ of wheat corn, $8 \%$ of maize, $5 \%$ of soy-extracted groats, $15 \%$ of soy oil, $23 \%$ of thermally treated soy, $5 \%$ of rape pressings, $12 \%$ of fish flour and $3 \%$ of a feed mineral supplement. It contained $210.04 \mathrm{~g}$ of nitrogenous substances $/ \mathrm{kg}$ and $17.52 \mathrm{MJ} / \mathrm{kg}$ of $\mathrm{pig}$ metabolisable energy from the transfer into the farrowing house. The daily intake of crude protein in the period from the transfer into the farrowing house until delivery was $525.1 \mathrm{~g}$. The daily intake of metabolisable energy was $43.80 \mathrm{MJ}$.

After delivery the sows were fed ad libitum with the feed mixture for lactating sows containing $158.2 \mathrm{~g}$ of nitrogenous substances $/ \mathrm{kg}$ of the feed mixture and $12.54 \mathrm{MJ} / \mathrm{kg}$ of metabolisable energy.

The nutritional values of the feeding mixtures were obtained by calculation.

Examination and evaluation

The total number of piglets in litter, the numbers of live and stillborn piglets and the mean birth weights of piglets were evaluated in the sows. In addition, the length of pregnancy was evaluated and blood samples from v. jugularis were taken on days 100,110 and 114 of pregnancy for progesterone, 17- $\beta$ oestradiol and cortisol determination in ten randomly selected sows in groups $\mathrm{A}$ and $\mathrm{B}$ and in all sows in groups $\mathrm{C}$ and $\mathrm{D}$. The length of pregnancy was defined as the period from the last insemination to delivery. The duration of delivery (the second stage) was defined as the interval between the expulsion of the first and the last piglets. Stillborn piglet was defined as displaying no signs of life after birth. The weights of the piglets were established by weighing the whole litter after the completion of delivery using a spring balance. The mean birth weight was calculated as the weight of the whole litter divided by the number of piglets of the litter. Blood samples were centrifuged after transfer to the laboratory and serum was frozen until assay. ELISA tests were used for progesterone and oestradiol (Immunolab, Germany) as well as cortisol (Biomeda, USA) determination.

The acquired data were processed statistically using the Kruskall Wallis non-parametrical ANOVA test in the QC Expert software.

\section{Results}

Length of pregnancy and delivery

Lengths of pregnancy in experimental groups A, B, C and D were $116.0 \pm 3.54,115.9$ $\pm 1.90,116.3 \pm 2.46$ and $116.4 \pm 3.27$ days, respectively. No significant differences were found between the groups. Although the mean duration of delivery gradually increased synchronously with the intake of crude protein from $4.5 \mathrm{~h}$ in group A to $8.6 \mathrm{~h}$ in group D (Fig. 1), significant difference was found only between groups A and D $(p<0.05)$.

\section{Numbers and birth weights of piglets}

Total numbers of piglets in litters, numbers of live as well as stillborn piglets and birth weights are shown in Table 1. The total numbers of piglets in experimental groups were 


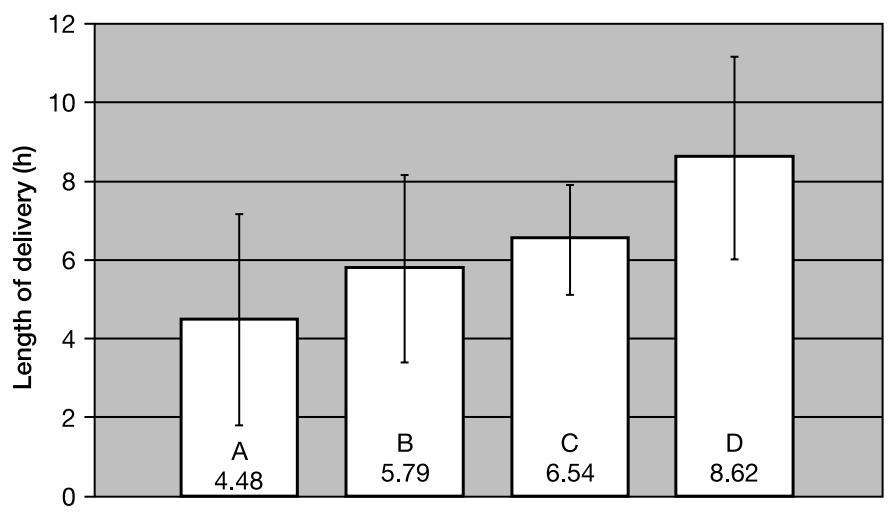

Fig. 1. Duration of delivery in the particular groups of sows

not significantly different and the values ranged from 10.1 (group D) to 10.5 (group C). The numbers of live piglets decreased and on the contrary the numbers of stillborn piglets increased successively from group A to group D. The difference between groups A and C, $\mathrm{D}$ and the difference between groups B and C, D was significant $(p<0.05)$. The average birth weights in experimental groups were not significantly different and the values ranged from $1.2 \mathrm{~kg}$ (group D) to $1.4 \mathrm{~kg}$ (group A and B).

Table 1. Mean numbers of all, live and stillborn piglets and average birth weights with various levels of crude protein contents in the feed

\begin{tabular}{|c|c|c|c|c|c|c|c|c|c|c|}
\hline \multirow{2}{*}{ Group } & \multirow{2}{*}{$\begin{array}{l}\text { Number } \\
\text { of sows }\end{array}$} & \multicolumn{7}{|c|}{ Numbers of births } & \multirow{2}{*}{ Weights } & \multirow{2}{*}{ SD } \\
\hline & & all & SD & live & SD & still* & $\%$ & SD & & \\
\hline $\mathrm{A}$ & 23 & 10.30 & 3.86 & 9.39 & 3.62 & 0.91 & 8.8 & 0.14 & 1.37 & 0.46 \\
\hline $\mathrm{B}$ & 52 & 10.20 & 2.81 & 9.06 & 2.54 & 1.14 & 11.2 & 0.22 & 1.42 & 0.28 \\
\hline $\mathrm{C}$ & 10 & 10.50 & 2.09 & 8.80 & 2.01 & 1.70 & 16.2 & 0.18 & 1.33 & 0.25 \\
\hline $\mathrm{D}$ & 10 & 10.10 & 1.54 & 8.10 & 2.85 & 2.00 & 19.8 & 0.25 & 1.21 & 0.33 \\
\hline
\end{tabular}

* A: C $p<0.05, \mathrm{~A}: \mathrm{D} p<0.05, \mathrm{~B}: \mathrm{C} p<0.05, \mathrm{~B}: \mathrm{D} p<0.05$

Table 2. Mean progesterone levels in the blood of sows before delivery with various crude protein content levels in the feed $(\mathrm{nmol} / \mathrm{l})$

\begin{tabular}{|c|c|c|c|c|c|r|r|}
\hline \multirow{2}{*}{ Group } & \multirow{2}{*}{$\begin{array}{c}\text { Number } \\
\text { of sows }\end{array}$} & \multicolumn{7}{|c|}{ Day of pregnancy } \\
\cline { 3 - 8 } & & mean & SD & mean & SD & mean & SD \\
\cline { 3 - 9 } & 10 & 32.50 & 6.52 & 22.64 & 4.58 & 10.91 & 5.09 \\
\hline A & 10 & 33.96 & 11.07 & 23.69 & 6.20 & 9.38 & 3.15 \\
\hline B & 10 & 32.18 & 3.12 & 21.84 & 2.77 & 10.05 & 1.59 \\
\hline C & 10 & 31.70 & 2.16 & 22.32 & 1.97 & 8.71 & 1.24 \\
\hline D & & & & & & \\
\hline
\end{tabular}

\section{Hormone concentrations}

Mean concentrations of progesterone in peripheral blood in experimental groups on days 100,110 and 114 of pregnancy varied between 32.50 and $31.70 ; 23.69$ and $21.84 ; 10.91$ and $8.71 \mathrm{nmol} / \mathrm{l}$, respectively (Table 2). Mean concentrations of plasma $17-\beta$ oestradiol in the groups on days 100,110 and 114 of pregnancy varied between 0.61 and $0.58 ; 0.97$ and $0.84 ; 0.60$ and $0.36 \mathrm{nmol} / 1$, respectively (Table 3 ). Mean concentrations of plasma cortisol increased non-significantly from group A to group $\mathrm{D}$. The mean values in individual groups on days 100, 110 and 114 of pregnancy varied between 131.10 and $75.95 ; 113.64$ and 
Table 3. Mean levels of 17- $\beta$ estradiol in the blood of sows before delivery with various crude protein content levels in the feed $(\mathrm{nmol} / \mathrm{l})$

\begin{tabular}{|c|c|c|c|c|c|c|c|}
\hline \multirow{2}{*}{ Group } & \multirow{2}{*}{$\begin{array}{c}\text { Number } \\
\text { of sows }\end{array}$} & \multicolumn{7}{|c|}{ Day of pregnancy } \\
\cline { 3 - 9 } & & \multicolumn{2}{|c|}{100} & \multicolumn{2}{|c|}{110} & \multicolumn{2}{c|}{114} \\
\cline { 3 - 9 } & 10 & 0.59 & 0.14 & 0.88 & 0.15 & 0.36 & 0.23 \\
\hline A & 10 & 0.61 & 0.10 & 0.97 & 0.23 & 0.60 & 0.53 \\
\hline B & 10 & 0.58 & 0.06 & 0.93 & 0.20 & 0.50 & 0.49 \\
\hline C & 10 & 0.60 & 0.05 & 0.84 & 0.17 & 0.49 & 0.46 \\
\hline D & & & & & & & SD \\
\hline
\end{tabular}

Table 4. Mean cortisol levels in the blood of sows before delivery with various crude protein content levels in the feed (nmol/l)

\begin{tabular}{|c|c|c|c|c|c|c|c|}
\hline \multirow{2}{*}{ Group } & \multirow{2}{*}{$\begin{array}{c}\text { Number } \\
\text { of sows }\end{array}$} & \multicolumn{7}{|c|}{100} & \multicolumn{2}{|c|}{110} & \multicolumn{2}{c|}{114} \\
\cline { 3 - 8 } & & mean & SD & mean & SD & mean & SD \\
\hline A & 10 & 75.95 & 25.49 & 68.61 & 20.83 & 71.62 & 40.42 \\
\hline B & 10 & 106.44 & 37.38 & 52.20 & 24.72 & 108.59 & 45.16 \\
\hline C & 10 & 110.96 & 60.89 & 87.37 & 41.24 & 102.49 & 41.33 \\
\hline D & 10 & 131.10 & 35.12 & 113.64 & 113.86 & 123.76 & 59.87 \\
\hline
\end{tabular}

$52.20 ; 123.76$ and $71.62 \mathrm{nmol} / 1$ respectively (Table 4). Differences in concentrations of any of the hormones on particular days were not significant between the experimental groups.

\section{Discussion}

One of the main goals of pig production is to wean more then 20 piglets from one sow per year. It requires an improvement of the know-how in the areas of nutrition and diet composition, management and husbandry techniques. For this reason our study focused on the relation of nutrient intake in sows to the course of delivery as well as the number and birth weights of piglets. There is not much information on the influence of crude protein in the last two weeks of gestation on the course of delivery and discussed variables of the progeny in literature.

We did not find any difference in the length of pregnancy in relation to the quality of diets by the end of pregnancy.

In our study the duration of the $2^{\text {nd }}$ stage of delivery (expulsion stage) gradually increased from the mean value of $4.48 \mathrm{~h}$ in group A to $8.62 \mathrm{~h}$ in group D synchronously with the increase of crude protein intake. Significant difference was found between groups A and D. We did not find any difference between the groups in the total numbers of piglets in litters. The mean values show a satisfactory rate of reproduction performance on the farm, ranging from 10.10 to 10.50 . However, there were differences in the numbers of live and stillborn piglets. The numbers of live piglets decreased and on the contrary, the numbers of stillborn piglets increased successively from group A to group D. Nevertheless, a significant difference was found only between the numbers of stillborn piglets from groups A and C, D and the numbers of stillborn piglets from groups B and C, D. Kudláč (1988) stated that absolutely and relatively large foetuses, prolonged time of delivery, higher age of sows and summer season as important factors positively influenced the occurrence of stillborn piglets. We can not evaluate the effect of age, birth weight or season because these variables were not different in all groups. However, our results support the data on the negative effect of prolonged delivery, as the number of stillborn piglets gradually increased synchronously with the increase of delivery length from group A to group D in our study, which is in accordance with reports of Randall (1972) and Friend et al. (1962). BilkeiPapp and Papp (1994) described a higher number of stillborn piglets in fat sows. Zaleski 
and Hacker (1993) describe higher probability of stillbirths in sows with a longer duration of gestation, lower mean birth weight of the litter, increasing age, higher condition score and larger litter score. The influence of these variables on the occurrence of stillbirths was not evaluated, as they did not differ between groups A, B, C and D. With regard to the infection causes of reproduction failure, all the sows were vaccinated regularly since entering the farm against porcine parvovirus and porcine reproductive and respiratory syndrome virus with inactivated vaccines. Other reproductive pathogens (Leptospira spp., Brucella abortus, Aujeszky disease virus, swine influenza virus) were not found on the farm during previous serological examination. Thus we can exclude these infection causes of stillbirths from our survey.

The mean birth weights in experimental groups were not significantly different and the values ranged from $1.2 \mathrm{~kg}$ to $1.4 \mathrm{~kg}$ in our study. Birth weight and variation in birth weight remain important risk factors for perinatal mortality (Van Der Lende 2001). Supplementing the diet with fat during the last month of pregnancy increases the birth weight of piglets and their energy resources and it increases the chance of their survival (Britt 1986). Likewise, a supplement of $1 \mathrm{~kg}$ of mixture per day during the last ten days of pregnancy increases the birth weight of piglets and prevents the loss of back fat in the sows below $1.5-2 \mathrm{~mm}$ (Aherne and Williams 1992). Cromwell et al. (1989) described that a higher feed intake during the last 23 days of gestation increases weights in newborn piglets by approximately $40 \mathrm{~g}$ and in 21 days old piglets by approximately $140 \mathrm{~g}$. In our study the higher intake of crude protein during the last 14 days of pregnancy had no effect on the birth weight of piglets, as the birth weights were not significantly different in all experimental groups.

We did not find any difference between the experimental groups in the concentrations of progesterone, 17- $\beta$ oestradiol and cortisol. The concentrations were characteristic for the time of sampling in all groups. Mean values of progesterone concentration decreased from the values of $9.97-10.68 \mathrm{ng} / \mathrm{ml}$ on day 100 to the values of $2.74-3.43$ on day 114 of pregnancy. Mean concentrations of 17- $\beta$ oestradiol and cortisol varied from 96.70 to $264.00 \mathrm{pg} / \mathrm{ml}$ and from 18.92 to $47.52 \mathrm{ng} / \mathrm{ml}$. The values are comparable with data stated by Wood (1999) and Miller (2004). Our results show that changes in the crude protein intake by the end of pregnancy did not affect the concentration of steroid hormones.

In conclusion, our results show that a high intake of crude protein in sows before parturition prolongs delivery and increases the number of stillborn piglets.

\section{Vliv příjmu dusíkatých látek na délku porodu a velikost vrhu u prasnic}

Cílem studie bylo stanovit vliv rozdílného př́imu dusíkatých látek prasnicemi v období od 94 - 100 dne gravidity do porodu na délku gravidity a porodu, počty a porodní hmotnosti selat a koncentrace progesteronu, 17- $\beta$ estradiolu a kortizolu ve 100., 110. a 114. dni gravidity. Denní př́ijem krmiva prasnice představoval 2,5 kg kompletní krmné směsi s obsahem $13 \%$ (skupina $\mathrm{A}, \mathrm{n}=23$ ), $15 \%$ (skupina $\mathrm{B}, \mathrm{n}=52$ ), $18 \%$ (skupina $\mathrm{C}, \mathrm{n}=10$ ) a $21 \%$ (skupina $\mathrm{D}, \mathrm{n}=10$ ) dusíkatých látek. V délkách gravidity nebyl mezi skupinami statisticky významný rozdíl. Průměrné délky porodu stoupaly s prŕíjmem dusíkatých látek, významný rozdíl byl nalezen mezi skupinami A $(4,5$ h) a D $(8,6$ h) $(p<0,05)$. Počty všech narozených selat se mezi skupinami významně nelišily. Počty živě narozených selat klesaly a počty mrtvě narozených selat stoupaly od skupiny A do skupiny D. Významný rozdíl byl nalezen mezi počty mrtvě narozených selat ve skupině A ve srovnání $\mathrm{k} C, \mathrm{D}$ a ve skupině $\mathrm{B}$ ve srovnání $\mathrm{k} \mathrm{C}, \mathrm{D}(p<0,05)$. Průměrné porodní hmotnosti selat se mezi pokusnými skupinami významně nelišily. Nebyl nalezen významný rozdíl mezi pokusnými skupinami v koncentracích sledovaných hormonů. Zvýšený př́ijem dusíkatých látek prasnicemi před porodem prodloužil porod a počet mrtvě narozených selat. 


\section{Acknowledgement}

This project was supported by the grant of MSM No. 6215712403.

\section{References}

AHERNE FX, WILLIAMS IH 1992: Nutrition for optimizing breeding herd performance. Vet Clin N Am Food Anim Pract 8: 589-608

BILKEI-PAPP G, PAPP GB 1994: Perinatal losses - general conditions of sows. III. Experiences obtained with prednisolone pretreatment. Magy Allatorv Lapja 49: 680-683

BRITT JH 1986: Improving sow productivity through management during gestation, lactation and after weaning. J Anim Sci 63: 1288-1296

CROMWELL GL, HALL DD, CLAWSON AJ, COMBS GE, KNABE DA, MAXWELL CV, NOLAND PR, ORR DE JR, PRINCE TJ 1989: Effects of additional feed during late gestation on reproductive performance of sows: a cooperative study. J Anim Sci 67: 3-14

FRIEND DW, CUNNINGHAM HM, NICHOLSON, JW 1962: The duration of farrowing in relation to the reproductive performance of Yorkshire sows. Can J Comp Med Vet Sci 26: 127-130

GREENHALGH JFD, ELSLEY FWH, GRUBB DA, LIGHTFOOT AL, SAUL DW, SMITH P, WALKER N, WILLIAMS D, YEO ML 1977: Coordinated trials on the protein requirements of sows. Anim Prod 24: 307-321

KUDLÁČ E 1988: Physiology and pathology of puerperium and influence of reproductive function in postnatal period in cows and sows. Dissertation. Univ Vet Pharm Sci Brno, 205 p.

MILLER HM, FOXCROFT GR, AHERNE FX 2004: Increasing feed intake in late gestation does not affect plasma progesterone concentration in the sow. Theriogenology 62:1618-1626

NOBLET J, CLOSE WH, HEAVENS RP, BROWN D 1985: Studies on the energy metabolism of the pregnant sow. 1. Uterus and mammary tissue development. Br J Nutr 53: 251-265

POND WG, STRACHAN DN, SINHA YN, WALKER EF JR, DUNN JA, BARNES RH 1969: Effect of protein deprivation of swine during all or part of gestation on birth weight, postnatal growth rate and nucleic acid content of brain and muscle of progeny. J Nutr 99: 61-67

POND WG 1973: Influence of maternal protein and energy nutrition during gestation on progeny performance in swine. J Anim Sci 36: 175-182

RANDALL GC 1972: Observations on parturition in the sow. II. Factors influencing stillbirth and perinatal mortality. Vet Rec 90: 183-218

VAN DER LENDE T, KNOL EF, LEENHOUWERS JI 2001: Prenatal development as a predisposing factor for perinatal losses in pigs. Reprod Suppl 58: 247-261

WOOD CE 1999: Control of parturition in ruminants. J Reprod Fertil 54: 115-126

ZALESKI HM, HACKER RR 1993: Variables related to the progress of parturition and probability of stillbirth in swine. Can Vet J 34: 109-113 